\title{
The Abortion Act (1967): a biography
}

\author{
Sally Sheldon ${ }^{1 \star}$, Gayle Davis ${ }^{2}$, Jane O’Neill ${ }^{2}$ and Clare Parker ${ }^{1,3 \dagger}$ \\ ${ }^{1}$ Kent Law School, University of Kent, Canterbury, UK, ${ }^{2}$ School of History, Classics and Archaeology, University of \\ Edinburgh, Edinburgh, UK and ${ }^{3}$ School of Humanities, University of Adelaide, Adelaide, Australia \\ ${ }^{\star}$ Corresponding author. Email: s.sheldon@kent.ac.uk
}

(Accepted 17 April 2018)

\begin{abstract}
In this paper, we set out what it means to offer a 'biography' of a law, illustrating the discussion through the example of the Abortion Act (1967), an important statute that has regulated a highly controversial field of practice for five decades. Biography is taken as a useful shorthand for an approach which requires simultaneous attention to continuity and change in the historical study of a law's life. It takes seriously the insight that written norms are rooted in the past, enshrining a certain set of historically contingent values and practices, yet that - as linguistic structures that can impact on the world only through acts of interpretation - they are simultaneously constantly evolving. It acknowledges the complex, ongoing coconstitution of law and the contexts within which it operates, recognising that understanding how law works requires historical, empirical study. Finally, it suggests that consideration of a law can offer a unique window through which to explore these broader contexts.
\end{abstract}

Keywords: abortion law; biography; health care law; legal history; Abortion Act 1967

\section{Introduction}

Every law has a biography. The Abortion Act (1967), which last year reached its fiftieth anniversary, offers a good subject to illustrate this claim. Following a conception in decades of political struggle, ${ }^{1}$ the Act was born at the height of the sexual revolution as part of a raft of liberalising legislation. ${ }^{2}$ It has been lauded as a key event in the liberation of women, ${ }^{3}$ and 'one of the finest, most humane and farsighted pieces of legislation in the twentieth century'; ${ }^{4}$ and lambasted as a transgression 'against the very basis of our mortal existence ${ }^{5}$ and symptomatic of all that has gone wrong with Britain. ${ }^{6}$ While controversy, often fuelled by activists and lobby groups, persists, fifty years on the Act has achieved a venerable status as one of the oldest pieces of statute law to govern an area of modern

\footnotetext{
${ }^{\dagger}$ We benefited greatly from early conversations about a biographical approach to law with Emilie Cloatre, David Nelken and Geoffrey Samuel; and from feedback on earlier drafts of this paper from John Coggon, Dave Cowan, Sheelagh McGuinness, Jesse Olszynko-Gryn, David Sugarman and two anonymous reviewers for Legal Studies. We acknowledge with gratitude the AHRC's support for our research ('The Abortion Act (1967): a biography'; AH/N00213X/1; www.kent. ac.uk/law/aa1967/index.html).

${ }^{1}$ Generally K Hindell and M Simms Abortion Law Reformed (London: Peter Owen, 1971).

${ }^{2}$ Including the Suicide Act (1961); the Murder (Abolition of Death Penalty) Act (1965); the Family Planning Act (1967); and the Sexual Offences Act (1967).

${ }^{3}$ Letter from Douglas Houghton to David Steel (6 February 1990), LSE archive STEEL/B/2/2.

${ }^{4}$ Editorial 'Let the Act act' (Medical News Tribune, 13 February 1970) 14.

${ }^{5} \mathrm{M}$ Muggeridge 'What the abortion argument is about' (Sunday Times, 2 February 1975).

${ }^{6} \mathrm{D}$ Alton What Kind of Country? (Marshall Pickering, 1988) p 168.

(C) The Society of Legal Scholars 2018. This is an Open Access article, distributed under the terms of the Creative Commons Attribution licence (http://creativecommons.org/licenses/by/4.0/), which permits unrestricted re-use, distribution, and reproduction in any medium, provided the original work is properly cited.
} 
medical practice. ${ }^{7}$ It has survived dozens of attacks in Parliament and been amended only once. ${ }^{8}$ While its text has endured largely without alteration, however, its legal and broader cultural meanings have evolved considerably over the last five decades.

While the study of legal biography is evolving in interesting and radical ways, ${ }^{9}$ it has thus far focused almost exclusively on human subjects. ${ }^{10}$ What does it mean to claim that the Abortion Act has a biography? The idea of 'biography' is itself culturally and historically contingent: Hermione Lee, the eminent biographer of Woolf and Gaskell, describes it as 'a shape-shifting, contradictory, variable form', lacking hard and fast rules. ${ }^{11}$ She nonetheless identifies a range of common features of the genre. Some - such as the requirement that the work should, so far as possible, endeavour to be objective - distinguish biography from other kinds of (literary) narrative but would be broadly accepted as a necessary goal in any robust legal or historical scholarship. ${ }^{12}$ Others do not apply straightforwardly to the study of a non-human subject. ${ }^{13}$ However, Lee identifies two typical features of biography that offer a useful starting point for the current analysis: first, biography is a form of history and, second, it should cover the subject's whole life or, at least, life to date. ${ }^{14}$ While not all biographies analyse their subjects from birth to death (or even to full maturity), the term 'biography' nonetheless suggests a historical span, promising more than a snapshot taken at one moment in time. It requires the historical, contextual study of a subject that is simultaneously attentive to both continuity and change within it over an extended period. This makes a 'biography' of the Abortion Act a very different exercise from an explanation of the factors which led to its introduction, ${ }^{15}$ or accounts of specific episodes in its life. ${ }^{16}$

Scholars have taken this broad insight as a starting point for moving beyond human subjects, offering biographies of such diverse objects as archaeological artefacts, diseases, and cities, ${ }^{17}$ emphasising that each cannot be fully understood at just one moment in its existence but, rather, must be examined as a continuing and evolving whole, which is always in the process of accumulating meaning. ${ }^{18}$ When applied to a statute, this approach has three major implications. First, it foregrounds a basic socio-legal insight: that law is a living thing, which needs to be studied as it is interpreted and takes effect in

\footnotetext{
${ }^{7}$ The entire statutory framework regulating abortion is contained within the first four of 270 pages of statutes extracted in the chronologically ordered AE Morris and MA Jones (eds) Blackstone's Statutes on Medical Law (Oxford: Oxford University Press, 5th edn, 2007).

${ }^{8}$ On the amendments, J Murphy 'Cosmetics, eugenics and ambivalence: the revision of the Abortion Act 1967' (1991) 13 (5) JSWFL 375. On early attacks see J Keown Abortion, Doctors and the Law: Some Aspects of the Legal Regulation of Abortion in England from 1803 to 1982 (Cambridge: Cambridge University Press, 1988); D Marsh and J Chambers Abortion Politics (London: Junction Books, 1981); D Paintin Abortion Law Reform in Britain (1964-2003): a Personal Account (London: BPAS, 2015) ch 7.

${ }^{9}$ L Mulcahy and D Sugarman 'Introduction: legal life writing and marginalized subjects and sources' (2015) 42(1) JLS 1.

${ }^{10}$ Note, however, an emergent study of legal objects, drawing in part on 'object biography': D Sugarman 'From legal biography to legal life writing: broadening conceptions of legal history and socio-legal scholarship' (2015) 42(1) JLS 7 at 32; A Perry-Kessaris (Guest Editor) Special Issue: The Pop Up Museum of Legal Objects (2017) 68(3) NILQ.

${ }^{11} \mathrm{H}$ Lee Biography: a Very Short Introduction (Oxford: Oxford University Press, 2009) p 18.

${ }^{12}$ While we all write from a position influenced by history, nationality, race, gender, class, education and beliefs, Lee notes that modern biography should nonetheless be distinguished from the 'opinionated and partial' life-writing of earlier centuries, ibid, pp 12-13.

${ }^{13} \mathrm{Eg}$ the author should know the subject; biography is an investigation of identity: ibid, ch 1 .

${ }^{14}$ Ibid.

${ }^{15}$ Hindell and Simms, above n 1, offer a detailed account of the introduction of the Abortion Act. For other important studies of the emergence of legislation, see WG Carson 'Symbolic and instrumental dimensions of early factory legislation: a case study in the social origins of criminal law' in R Hood (ed) Crime, Criminology and Public Policy (London: Heinemann, 1974); D Nelken The Limits of the Legal Process: a Study of Landlords, Law and Crime (London, Academic Press, 1983).

${ }^{16} \mathrm{Eg}$ Marsh and Chambers, above n 8, offering a detailed exploration of a specific reform attempt.

${ }^{17}$ Eg C Gosden and Y Marshall 'The cultural biography of objects' (1999) 31(2) World Archaeology 169; S Mukherjee The Emperor of All Maladies: A Biography of Cancer (London: Fourth Estate, 2011); P Ackroyd, London: The Biography (London: Chatto \& Windus, 2000).

${ }^{18}$ I Kopytoff 'The cultural biography of things: commoditization as process' in A Appadurai (ed) The Social Life of Things: Commodities in Cultural Perspective (Cambridge: Cambridge University Press, 1988).
} 
practice, rather than merely as it exists on the statute books. ${ }^{19}$ Even where a statute's text remains unchanged, its acquisition of legal meaning is an ongoing process, which involves interpretative work; development and consolidation of received understandings; evolving practices; and moments of challenge, rupture, and revision. Such evolution in meaning inevitably both reflects and influences the shifting broader social and institutional contexts within which a law is read, understood and applied. Second, a statute - and particularly one characterised by considerable controversy - also acquires a broader social and symbolic meaning, which stands in no necessary relationship either to the intention of its drafters or to its doctrinal meaning, as developed by lawyers. The stories told about a law - and what that law represents in broader cultural terms - can and will evolve, whilst at times revealing roots which go deep into its history. Finally, the subject of a biography can offer a window through which to study aspects of the world evolving around it. ${ }^{20}$ Biography must offer the story of the stream as well as that of the fish. ${ }^{21}$

A comprehensive account of the Abortion Act's long and complex biography is far beyond the scope of this paper. ${ }^{22}$ Here, in a necessarily brief and highly selective account, we seek to illustrate a few of the insights which might be gleaned from a biographical approach by focusing on two episodes involving 'sting' operations at either end of the Act's life: a recent Daily Mail investigation into services at Marie Stopes International; ${ }^{23}$ and the Babies for Burning report of the early 1970 s. $^{24}$ Each claimed to cast a spotlight on how the Abortion Act was working in practice. Considering them together offers useful insights into change and continuity in its meanings.

\section{Two episodes in the life of the Abortion Act}

The Abortion Act (1967) applies in England, Wales and Scotland but not Northern Ireland. It carves out an exception whereby criminal offences under the law relating to abortion will not be committed, ${ }^{25}$ provided that a pregnancy is terminated under medical control. Specifically, the abortion must be performed on NHS or licensed premises, by a registered medical practitioner, and following a good faith opinion that it might be justified under one of several broad grounds set out in the Act. ${ }^{26}$

Individual doctors enjoy wide discretion under this provision and, unsurprisingly, they have exercised it to different effect. In 1970, some $10 \%$ of consultant gynaecologists freely allowed access to abortion; 6\% objected to it in any circumstances; and the rest interpreted the Abortion Act as seemed best to them in the light of their medical knowledge and the patient's needs, ${ }^{27}$ no doubt representing the full spectrum of more permissive and restrictive interpretations beyond these two extremes. GPs tended towards a more liberal reading of the Act, contributing to a significant, immediate increase in referrals into the NHS. One gynaecologist noted ruefully:

\footnotetext{
${ }^{19}$ For the significance of focusing on 'technical law' as part of this project see D Cowan and D Wincott 'Exploring the legal' in D Cowan and D Wincott (eds) Exploring the 'Legal' in Socio-Legal Studies (London: Palgrave, 2015).

${ }^{20} \mathrm{M}$ Gillings and J Pollard 'Non-portable stone artifacts and contexts of meaning' (1999) 31(2) World Archaeology 179.

${ }^{21}$ Describing the difficulty of writing her own memoir, Woolf observed, 'I see myself as a fish in a stream; deflected; held in place; but cannot describe the stream': V Woolf 'Sketch of the past' in Moments of Being (London: Pimlico, 2002) p 90.

${ }^{22}$ For a fuller account see G Davis, J O'Neill, C Parker and S Sheldon The Abortion Act 1967: a Biography of a UK Law (Cambridge: Cambridge University Press, forthcoming).

${ }^{23} \mathrm{~K}$ Faulkner and S Smyth 'Abortions signed off after just a phonecall: how Marie Stopes doctors approve abortions for women they've never met' (Daily Mail, 6 March 2017).

${ }^{24} \mathrm{M}$ Litchfield and S Kentish Babies for Burning: the Abortion Business in Britain (Serpentine Press, 1974). At the time of writing, extensive and previously unstudied resources on Babies for Burning were held by BPAS, which was named in the investigation and actively involved in rebutting its allegations. The files are now held by the Wellcome Library, which has made some of them publicly available. References here relate to the files as organised in the BPAS holding.

${ }^{25}$ Notably, ss 58 and 59 of the Offences Against the Person Act (1861) and the Infant Life Preservation Act (1929) (for England and Wales); and common law offences (for Scotland).

${ }^{26}$ Abortion Act 1967, s 1(1). An exception is made for conditions of emergency, s 1(4).

${ }^{27}$ TRT Lewis 'The Abortion Act (1967): findings of an inquiry into the first year's working of the act conducted by the RCOG’ (1970) 2 BMJ 529.
} 
'all in all, we [the RCOG] did not expect a very great change in practice from that obtaining before the Act. We thought there would be a slightly more liberal attitude to the problem, for that, after all, was the purpose of the new law. How wrong we were'. ${ }^{28}$

The rate of legal abortions rose sharply after the introduction of the Act. While 2,800 legal terminations were reported in the whole of 1962, almost 10,000 were performed in the fourth quarter of 1968 alone. ${ }^{29}$ Numbers continued to increase rapidly over subsequent years, reaching 167,149 in 1973 for England and Wales alone, before declining slightly over subsequent years. ${ }^{30}$ With Britain at the international vanguard of liberalising legislation, particular concern was provoked by the fact that over 50,000 of these were 'abortion tourists', seeking to avoid more restrictive laws elsewhere. ${ }^{31}$ The immediate impact within the NHS, where no additional resources had been made available to cope with increased demand, was dramatic. While the rise in legal abortions was accompanied by a decline in sepsis cases resulting from the decline in illegal ones, it was practically difficult to redeploy the beds thus freed. ${ }^{32}$ In the face of rapidly growing waiting lists for other routine gynaecological procedures, doctors came under pressure to refuse women seeking abortion or to accept them only from within a given catchment area. ${ }^{33}$ This exacerbated a marked disparity in the availability of NHS services, with $99 \%$ of abortions in Newcastle but just over $20 \%$ in Birmingham funded by the NHS in $1970 .{ }^{34}$ Private and charitable abortion services, with negligible refusal rates, quickly developed in regions where NHS services were limited. The British Pregnancy Advisory Service was initially established as the Birmingham Pregnancy Advisory Service, with the aim of addressing specific problems in local service provision. ${ }^{35}$

While reducing maternal mortality and morbidity, ${ }^{36}$ the early years of the Abortion Act were also marked by incidents of serious abuse. Some exploited the greater freedom offered by the Act, 'battening on hard-up girls' to offer 'abortions with the minimum amount of care for the maximum of money. ${ }^{37}$ Later abortions emerged as a focus of particular controversy, with regular 'horror stories' reported of live aborted fetuses left to die without basic care. ${ }^{38}$ An early report went further still, claiming that whole live fetuses were being sold for use in research. ${ }^{39}$ While ultimately shown to be unfounded or misleading, each of these initial reports gained far more attention than the subsequent investigations disproving their claims. ${ }^{40}$

\footnotetext{
${ }^{28}$ TRT Lewis 'The Abortion Act' (1969) 1:5638 BMJ 241 at 241.

${ }^{29} \mathrm{Ibid}$

${ }^{30}$ Registrar General's Statistical Review of England and Wales, Supplement on Abortion (1974).

${ }^{31}$ Ibid. See further Report of the Committee on the Working of the Abortion Act (the Lane Report) (April 1974) Cmnd 5579 at [457]-[470]. 'Abortion tourism' declined rapidly as neighbouring countries followed the UK in liberalising their laws.

${ }^{32}$ A Hordern Legal Abortion: the English Experience (Oxford: Pergamon Press, 1971) ch 8. There is insufficient data to trace a corresponding decrease in illegal abortion: M Simms 'Abortion law reform: how the controversy changed' [1970] Crim LR 567; JM Finnis 'The Abortion Act: what has changed?' [1971] Crim L Rev 3.

${ }^{33} 82,787$ gynaecology patients were awaiting non-urgent NHS operations in December 1968, at a time when only 436 FTE of consultant gynaecologists worked in England and Wales, Hordern, ibid, p 105.

${ }^{34}$ Lane Report, Volume II: Statistical Volume, table 6.5(a).

${ }^{35}$ Paintin, above n 8 , ch 5 .

${ }^{36}$ D Steel, HC Deb, vol 885, cols 1764-1777, 7 February 1975, lists the positive impacts on women's health. See further, Lane Report, above n 31, at [507].

${ }^{37} \mathrm{D}$ Devlin 'Investigating the abortion laws' (General Practitioner, 1 November 1974).

${ }^{38} \mathrm{BPAS}$ (undated) The Foetus Myth, gathers together media reports of 'a steady stream of horror stories', dating from 1970-1979. BPAS uncatalogued.

${ }^{39}$ Evening News Reporters “'Unborn Babies For Sale” - Anger Flares' Evening News (16 May 1970); N St John-Stevas ‘The scandal of the foetuses' (Catholic Herald, 22 May 1970).

${ }^{40} \mathrm{An}$ anonymous introduction to BPAS, above $\mathrm{n} 38$, notes 'when investigations have shown the original stories to be untrue or distorted or inaccurate, the publicity given to the correct versions has been very much less - and very much less prominent'. Lane, above n 31, at [279(1)] reported giving 'anxious consideration' to these stories but finding no evidence for any case of a fetus of less than 24 weeks' gestation being viable.
} 
The Government responded with the establishment of two review bodies. The first focused on the use of fetal remains in research, ${ }^{41}$ producing a Code of Practice, which was adopted across the sector. ${ }^{42}$ The second, the Lane Committee, conducted an extensive, three-year investigation into the workings of the Act. It found clear evidence of a small number of 'commercial entrepreneurs' who exploited vulnerable women, engaging in extensive advertising and touting for, and even 'hi-jacking', women from train stations and airports. ${ }^{43}$ While evidence of such abuses had led to calls for the Abortion Act to be amended, Lane rejected this conclusion, ${ }^{44}$ suggesting rather that they might be addressed through more robust regulation. These recommendations were broadly endorsed by a Select Committee and followed by the Government. ${ }^{45}$ The use of regulation here emerged as an important means of seeking to address concerns regarding the operation of the Act, in a way which avoided allowing Parliament the opportunity to amend it, ${ }^{46}$ a role which it has continued to play.

In 1974, shortly before Lane was due to report and with controversy regarding the Act at its peak, a storm erupted around allegations made by two freelance journalists in a series of reports in the News of the World under the banner, Phantom Babies, ${ }^{47}$ and later a book, Babies for Burning. ${ }^{48}$ Michael Litchfield and Susan Kentish promised:

'a terrifyingly stark and graphic account of two people probing every facet of the private sector of the abortion industry. One harrowing experience after another is assimilated into a disturbing dossier that should make even the most hardened pro-abortionists re-examine their dogma. Phantom pregnancies, girls-for-hire by a doctor as baby-producing 'machines', babies sold to cosmetic factories to be churned into soap, are but a few of the macabre and grisly features of this important but chilling social document. ${ }^{49}$

Posing as a couple facing an unwanted pregnancy, Litchfield and Kentish had visited a range of pregnancy testing services, doctors' surgeries, and abortion clinics, apparently uncovering a horrific level of abuse. They carried with them a concealed tape recorder, allowing them to promise that '[e]very fact we state, we can prove. ${ }^{50}$ However, after some months, it became apparent that recordings of the most shocking incidents which they described (including that of the 'babies to be churned into soap') were unavailable or inaudible. ${ }^{51}$ A Sunday Times investigation exposed the falsity and lack of corroboration of many of the stories told in the book. ${ }^{52}$ A number of parties sued for defamation. ${ }^{53}$ Babies for Burning's publisher was liquidated; its authors bankrupted. ${ }^{54}$

\footnotetext{
${ }^{41}$ The Use of Fetuses and Fetal Material for Research: Report of the Advisory Group (the 'Peel Report') (London: HMSO, 1972).

${ }^{42}$ DHSS Circular Code of Practice for Fetal Research: Recommendations of Sir John Peel's Advisory Group (23 May 1972) no 72/154: Wellcome SA/ALR/G.8.

${ }^{43}$ Lane Report, above n 31, at [436].

${ }^{44}$ Ibid.

${ }^{45}$ Barbara Castle, Secretary of State for Social Services HC Deb, vol 898, cols 244-247, 21 October 1975, describing the resulting changes in regulation.

${ }^{46}$ The then Health Minister has described his reluctance to allow Parliament to vote again on abortion law reform and the role played by regulation in staving off this possibility: David Owen Time to Declare (London: Michael Joseph, 1991 ) p 229.

${ }^{47}$ The reports were trailed on 24 February 1974, appearing over the three following weeks.

${ }^{48}$ Litchfield and Kentish, above $\mathrm{n} 24$.

${ }^{49}$ Litchfield and Kentish, above n 24, back cover.

${ }^{50}$ Litchfield and Kentish, above n 24, pp 11-12.

${ }^{51}$ Minutes of Evidence, House of Commons Select Committee on the Abortion Amendment Bill (7 July 1975), [1282][1294], [1301].

${ }^{52} \mathrm{O}$ Gillie, M Wallace, P Ashdown-Sharp, and L Zimmerman 'Abortion horror tales revealed as fantasies' (Sunday Times, 30 March 1975).

${ }^{53}$ Lafitte and Others $v$ Serpentine Press and Others, QBD, apology read in open court (26 January 1978); Pond $v$ News Group Newspapers QBD (11 July 1980 unreported); Pond $v$ Litchfield and Kentish QBD (8 December 1982, unreported); Bloom v Litchfield, Kentish and Others QBD (7-8 March 1977, unreported). Extensive documentation relating to each action was held in the BPAS archive. The authors' action against the Sunday Times was withdrawn.

${ }^{54}$ Various papers relating to Serpentine's liquidation, BPAS, Pocket Folder 2; Summary of Debtor's Statement of Affairs for Kentish (4 August 1981) and Litchfield (19 February 1982). BPAS, Misc 1.
} 
While the precise impact of this investigation is impossible to gauge, it was certainly significant. It was reported across the News of the World's front pages for four weeks, at a time when it was the 'World's Largest Sunday Sale, ${ }^{55}$ reporting a circulation of 5.5 million. ${ }^{56}$ Several early reviews reproduced the book's claims uncritically, ${ }^{57}$ and one commentator noted that it was 'certainly the most influential medical book of the 1970s, simply because so many people believed its fantastic allegations'. ${ }^{58}$ Babies for Burning was republished in at least four languages and quickly became established as the 'bible of the pro-life movement'. ${ }^{59}$ Litchfield addressed large Pro-Life rallies; ${ }^{60}$ and the authors were interviewed on national radio. ${ }^{61}$

The investigation had a clear impact on early attempts to restrict the Abortion Act. ${ }^{62}$ One MP is said to have based his personal research for his 1975 abortion bill on reading the proofs, ${ }^{63}$ and others explicitly attributed their support for it to the book. ${ }^{64}$ Litchfield and Kentish were invited to give evidence to an important Parliamentary Select Committee, ${ }^{65}$ which in turn influenced further measures aiming to restrict the Act. ${ }^{66}$ However, the public unravelling of the book's more extreme claims may equally have militated against reform: with its most shocking claims revealed as 'fantastic', any truth in its more credible allegations may also have been treated with a large grain of salt. ${ }^{67}$

While it was without doubt the most important scandal to have engulfed the Abortion Act, more than forty years on, Babies for Burning has been largely forgotten. Currently, around 200,000 abortions are performed each year within the now well-embedded regulatory framework established by the Abortion Act. ${ }^{68}$ Almost all terminations performed in Scotland are performed within the NHS. For England and Wales, around one third of abortions are performed within NHS facilities, with the remainder largely provided by two large charities operating under NHS contract: the British Pregnancy Advisory Service (BPAS), which has now expanded far beyond its initial base in Birmingham, and Marie Stopes International (MSI). ${ }^{69}$ However, criticism of the Abortion Act has persisted, with its operation scrutinised through the ongoing use of media 'stings', which have become a significant and recurrent feature of its life.

Most recently, a Daily Mail investigation followed up on the findings of a Care Quality Commission (CQC) inspection of MSI. ${ }^{70}$ The CQC had identified a string of flaws in service provision ranging from basic failures in governance, clinical care and safeguarding, to criticism of how the approval requirements under the Abortion Act were met, with doctors seen bulk signing abortion certificates. ${ }^{71}$ The Mail investigation was far more limited than Babies for Burning in its scope. It reported some of

\footnotetext{
${ }^{55}$ News of the World front cover (3 March 1974).

${ }^{56}$ Kentish, Bloom above n 53, cross-examination of Mrs Susan Kentish, transcript at 7, BPAS Misc 2.

${ }^{57} \mathrm{R}$ Butt 'This awful silence hanging over abortion on demand' (The Times, 23 January 1975); L Abse 'Leo Abse MP on the murder trade of the London abortion clinics' (Spectator, 18 January 1975); Muggeridge, above n 5.

${ }^{58} \mathrm{D}$ Devlin 'Book for burning?' (The General Practitioner, 20 January 1978).

${ }^{59} \mathrm{~F}$ Lafitte, affidavit in Lafitte and Others, above n 53, BPAS, Evidence 4.

${ }^{60}$ The World this Weekend BBC Radio 4 (28 April 1974) transcript on file, BPAS, Pocket Folder 2 reported that Litchfield would be addressing a 'massive public meeting' in Hyde Park.

${ }^{61}$ Eg ibid and The Jimmy Young Show, BBC Radio 2 (27 December 1974), transcript, BPAS, Pocket Folder 2.

${ }^{62}$ Generally, Marsh and Chambers, above n 8, pp 27-28.

${ }^{63}$ James White MP, interviewed in the Scottish Daily Record (5 December 1975).

${ }^{64}$ Marsh and Chambers, above n 8 .

${ }^{65}$ Select Committee, above n 51.

${ }^{66}$ Marsh and Chambers, above n 8.

${ }^{67}$ The BPAS Public Relations Officer writes: 'without doubt, with the credibility of "Babies for Burning" completely undermined, the credibility of much of the anti-abortion lobby's argument has also been destroyed'. D Munday 'Introduction' in $A$ Book for Banishing: 'Special Supplement', BPAS Newsletter Feb 78, BPAS Unnamed 1, 1.

${ }^{68}$ Department of Health Abortion Statistics, England and Wales: 2016 (June 2017); ISD Termination of Pregnancy Statistics Year ending December 2016 (30 May 2017).

${ }^{69}$ Ibid.

${ }^{70}$ CQC Marie Stopes International: Quality Report (20 December 2016).

${ }^{71}$ Clinicians were seen signing piles of 30-60 forms, on the basis of just the 'reason for termination' information noted on the back, without necessarily having access to all patient information. Ibid, at 36 .
} 
the CQC's concerns and described how Mail journalists were apparently accepted as eligible for terminations services on the basis of a brief conversation with a call centre worker. ${ }^{72}$ While the CQC inspection report was widely reported by the national press, the Mail sting received relatively little coverage in other mainstream media. However, it nonetheless offers a useful point of comparison to Babies for Burning. Below we consider a central concern in each 'sting': doctors' gatekeeper role in access to abortion services. A closer consideration of these two episodes, occurring at either end of the Act's long life, suggests significant continuity but also evolution in how the Act is interpreted and in the broader stories told about it. It is in requiring our simultaneous attention to such change and continuity that the biographical approach may prove illuminating.

\section{Continuity and change in legal meaning}

The passage of a statute through Parliament marks only the beginning of its existence. After being signed into law, it becomes subject to the industry of lawyers and others, who go to work on how it is to be interpreted. ${ }^{73}$ Those whose activities are affected will consider how best to apply it, sometimes translating it into professional codes or internal policy and procedure documents, sometimes flouting it or pushing at its perceived limits and potentially expanding or contracting them through their interpretation of the text. A law can sometimes be ignored, languishing on the statute books despite being disregarded. ${ }^{74}$ It can operate as a more or less important part of the background to the norms informing daily life, offering a last resort when all other efforts to resolve a dispute have failed, with a limited or only indirect impact on day-to-day life. ${ }^{75}$ Alternatively, it can have an influence that goes far beyond that foreseen by its drafters or justified by its wording. ${ }^{76}$ Even when a dispute comes to court, judges enjoy considerable discretion in the interpretation of statutory norms, with the mere fact of judicial division on a particular question itself indicating the inherent openness and indeterminacy of law. While such a position is fiercely contested, some have gone so far as to argue that the existing body of legal doctrines permits a judge to justify any result he or she desires in any particular case. ${ }^{77}$

Relatively few cases regarding the Abortion Act have been considered by the courts, with still fewer reaching the Supreme Court or its predecessor, the House of Lords. ${ }^{78}$ However, before turning to the focus on clinical decision-making at the heart of the two 'stings' discussed above, it is worth offering one of these cases as a brief illustration of how legal meaning can be created by courts. RCN $v$ DHSS (1981) turned upon the role of nurses and midwives in abortion procedures. While in 1967, doctors had performed abortions using surgical techniques, by the early 1980s many second trimester abortions were carried out using drugs to provoke uterine contractions, a process which might last anything up to $18-30$ hours. $^{79}$ In these procedures, it was common practice for a doctor to insert a catheter into the woman and then to remain available on call, while all steps directly causative of the abortion were carried out by a nurse or midwife. While the legality of this practice was confirmed

\footnotetext{
${ }^{72}$ Faulkner and Smyth, above n 23.

${ }^{73} \mathrm{R}$ Cotterell The Sociology of Law: an Introduction (London: Butterworths, 2nd edn, 1992) p 1.

${ }^{74}$ For some interesting (including some apocryphal) examples, see Law Commission Legal Curiosities: Fact or Fable?, available at www.lawcom.gov.uk/wp-content/uploads/2015/03/Legal_Oddities.pdf.

${ }^{75} \mathrm{R}$ Pound 'Law in books and law in action' (1910) 44 American Law Review 12.

${ }^{76}$ Some interviewees in an Irish study were reluctant to speak about abortion law reform, wrongly believing even this was illegal under laws restricting the provision of information regarding abortion services: Amnesty International She is not a Criminal: the Impact of Ireland's Abortion Laws (London: AI, 2015).

${ }^{77}$ For critical discussion of this approach, typically associated with the Critical Legal Studies movement see LB Solum 'On the indeterminacy crisis: critiquing critical dogma' (1987) 54 University of Chicago Law Review 462. For a careful and nuanced exploration of the scope available to judges in statutory interpretation and the constraints upon their reasoning see N Duxbury Elements of Legislation (Cambridge: Cambridge University Press, 2012), particularly Part III; and The Nature and Authority of Precedent (Cambridge: Cambridge University Press, 2008).

${ }^{78}$ RCN v DHSS [1981] 1 All ER 545; Janaway $v$ Salford HA [1988] 3 All ER 1079; Greater Glasgow Health Board v Doogan [2014] UKSC 68.

${ }^{79} \mathrm{RCN}$, ibid.
} 
in official guidance, ${ }^{80}$ the Royal College of Nursing queried whether it might properly be considered to fall within the requirement under the Act that a pregnancy must be 'terminated by a registered medical practitioner'. ${ }^{81}$

The 'correct meaning' of the Abortion Act was unclear on this point, ${ }^{82}$ with ample 'room for two views ${ }^{83}$ and judges divided between them. ${ }^{84}$ However, a slim majority in the House of Lords ultimately concluded that the provision was best understood as meaning that a doctor 'should accept responsibility' for all stages of an abortion, without necessarily needing to carry out specific actions him or herself. ${ }^{85}$ Importantly, while the meaning of the Act is here laid down by the courts, heavy reliance is placed on understandings which had already been developed in clinical settings. The judges noted a reluctance to disrupt safe, effective established medical practice, ${ }^{86}$ avoiding the potential consequence of a narrower reading of this provision: that some 8,500 women each year might either face abortions performed by more dangerous surgical methods or be refused NHS treatment altogether. ${ }^{87}$

Both Babies for Burning and the Mail investigation focused heavily on the acquisition of meaning of another important requirement laid down in the Abortion Act: that two doctors must form a good faith opinion that a termination may be justified in line with one of the broad grounds laid down within it. From the outset, a large majority of abortions were authorised on the basis of the first such ground: that 'the continuance of the pregnancy would involve risk, greater than if the pregnancy were terminated, of injury to the physical or mental health of the pregnant woman or any existing children of her family', ${ }^{88}$ with doctors able to take account of the pregnant woman's 'actual or reasonably foreseeable environment' in reaching their decision. ${ }^{89}$ While this wording left considerable scope for clinical discretion, ${ }^{90}$ it had not been intended by the Act's sponsor that it should 'leave a wide open door for abortion on request'. ${ }^{91}$ However, just as a broad interpretation has given the Act a meaning capable of accommodating technical developments in abortion methods, so too has there been clear evolution in understandings of appropriate decision-making within the terms of the Act, with existing medical practice again offering an important reference point in giving it meaning. ${ }^{92}$

As noted above, individual clinicians interpreted this provision of the Act differently, with charities and private practice developing to offer abortions where NHS services were unavailable. Litchfield and Kentish deliberately targeted these non-NHS providers, finding clear evidence that abortion was available 'on demand' within some of them. One service provider had told Kentish that while she could obtain an abortion in a private clinic, she wouldn't stand 'an earthly chance' within the NHS for, after all, 'what good reason have you got to say you don't want this child?'93 Another emphasised that two gynaecologists would make a final decision but advised that if you did not want to have a child at all - that's good enough for them'. ${ }^{94}$ A third reassured her that while she would need to

\footnotetext{
${ }^{80}$ Letter to doctors and nursing officers from Dame Phyllis Friend (CNO) and H Yellowlees (CMO), 21 February 1980, RCOG/A/16/19.

${ }^{81} R C N$, above n 78 .

${ }^{82}$ A letter from the RCOG President (17 December 1979) expresses dismay at ongoing indecision about the correct meaning of the 1967 Act', RCOG/A/16/19.

${ }^{83}$ JC Smith 'Cases and comment: RCN v DHSS (HL)' [1981] Crim LR 322 at 323.

${ }^{84}$ Woolf J (QBD), Lords Diplock, Keith and Roskill (HL) ultimately concluding in favour of the Department; Lord Denning MR, Brightman LJ and Sir George Baker P (CA), Lords Wilberforce and Edmund-Davies (HL) favouring a more restrictive reading, $R C N$, above $\mathrm{n} 78$.

${ }^{85}$ [1981] 1 All ER 545, Lord Diplock, 569-70; Lord Keith, 575; Lord Roskill, 577.

${ }^{86}$ Ibid, Lord Roskill, 577; Lord Keith, 575. Cf Denning MR, 557.

${ }^{87}$ Letter to the CMO from JS Metters 'Medical Induction Terminations' (12 November 1980), NA MH156/579.

${ }^{88}$ Abortion Act 1967, s 1(1)(a).

${ }^{89}$ Ibid, s 1(2).

${ }^{90}$ Generally, Keown, above n 8, ch 5 .

${ }^{91}$ Steel, HC Deb, vol 732, cols 1075, 22 July 1966.

${ }^{92} R$ v Smith [1974] 1 All ER 376, CA, noting that without evidence as to professional practice and medical probabilities, a verdict against a doctor was often likely to be unsafe.

${ }^{93} \mathrm{M}$ Litchfield and S Kentish 'Abortions with a chauffeur service' (News of the World, 17 March 1974).

${ }^{94} \mathrm{M}$ Litchfield and S Kentish 'If you don't want a child, that's good enough' (News of the World, 17 March 1974).
} 
see two doctors, all that mattered were the couple's 'private reasons', and that it was 'nothing to do with anybody else'. 95

Litchfield and Kentish's account of their meeting with Dr Philip Bloom, a psychiatrist specialising in psycho-sexual problems, offers a particularly revealing insight into how the Abortion Act was interpreted and implemented in the early 1970s. Bloom assessed Kentish in her guise of a married woman who simply did not want children. He operated openly from an address at the heart of the medical establishment, requiring moderate payment by the standards of Harley Street. There was no suggestion that he had encouraged Kentish to end her (fictitious) pregnancy: he twice checked whether she was sure of her decision and once whether she had considered adoption. ${ }^{96}$ With the recording of their interview available, there was little dispute as to facts, ${ }^{97}$ meaning that the case turned squarely on conflicting interpretations of the requirements of the medical gatekeeper role foreseen within the Abortion Act. As the judge summarised the question to the jury in Bloom's subsequent defamation action: had Bloom offered a good faith opinion 'correctly formed on adequate material' or rather a 'reckless, casual, incompetent' one? ${ }^{98}$

In the words of the News of the World, Bloom had asked:

"Were you a bed-wetter as a child? Occasional depression sometimes? Sex side alright? Do you tend to be a perfectionist at home?" When he asked, "You don't swoon over babies?" Sue replied: "No, I mean I like other people's babies." In the end, Dr Bloom said: "Well, I don't see any purpose in having a child you don't want."”

Bloom certified the need for an abortion on the basis that Kentish had no maternal feelings and might react neurotically to an unwanted pregnancy. ${ }^{99} \mathrm{He}$ complained that while this had been a 'perfectly normal interview'100 and that 'one must respect a woman's right to choose whether she has a baby or whether she should not have a baby', he had nonetheless been included in a 'rogues' gallery' of 'a multimillion pound industry'. ${ }^{101}$

Litchfield and Kentish robustly defended a very different view, claiming that if Kentish qualified for an abortion on the basis of that interview, 'then no woman is fit to bear a child [.... The doctors are supposed to establish, regardless of the wishes of the mother, whether or not it will be harmful for her to have a child. The distinction is not that subtle'. ${ }^{102}$ Kentish told the Court that they had found that the Abortion Act was 'abused and treated with contempt': ${ }^{103}$

'We looked at the letter [to the gynaecologist, setting out Bloom's reasons for approving the abortion], we compared it with the consultation and we found it quite amazing and shocking that he should write this letter on the basis of such a consultation and could indeed sign an abortion form. We found him wanting in good faith'. ${ }^{104}$

The jury were thus invited to consider whether Bloom had properly fulfilled the gatekeeper role foreseen for him in the Abortion Act. ${ }^{105}$ They found in his favour, suggesting that they were not convinced

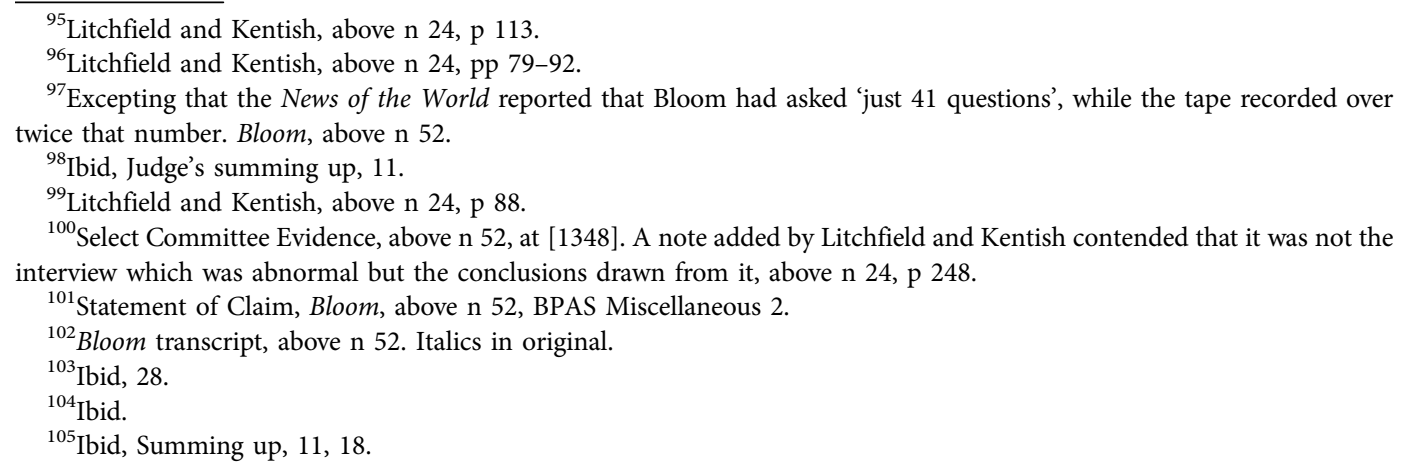


of the substantial truth of the allegations against him, but awarded only nominal damages, implying little sympathy for him. ${ }^{106}$

Bloom both highlights the extent to which the correct interpretation of this provision of the Abortion Act was under active dispute in the early years of the Abortion Act's operation and offers important confirmation of the breadth of discretion that the Act accords to medical gatekeepers. It also demonstrates the significance of medical practice in determining whether a doctor can claim to have acted lawfully and, thus, in giving the Act meaning. The Bloom court accepted this as an essential reference point in determining what was required to demonstrate a 'good faith' judgment, with detailed evidence offered by expert witnesses for both sides. ${ }^{107}$ Finally and significantly, Bloom illustrates the significant work done to meet the requirements of the Abortion Act in the 1970s. At that time around one third of all psychiatrists believed - like Bloom - that abortion should be available to any woman who did not wish to continue a pregnancy. ${ }^{108}$ Even for those who took a permissive reading of the legislation, however, acting in good faith involved close scrutiny of a woman's reasons for seeking to end a pregnancy and, if approved, the construction of a detailed account of how an abortion could be justified, mapped to the terms of the Abortion Act. At around the same time, a rare prosecution for illegal abortion of a doctor who had acted with the necessary second signature foreseen in the Abortion Act relied on the fact that he was found not to have acted in good faith, having asked virtually no questions regarding the woman's situation nor, indeed, performed basic medical tests. ${ }^{109}$

While the relevant statutory text at issue has remained unaltered since Bloom, this central aspect of how the Act is operationalised within clinical practice has changed significantly since the 1970s. While still stigmatised, abortion services are now entrenched as an essential part of mainstream healthcare, with almost all procedures funded by the NHS. ${ }^{110}$ Bloom's belief that one must respect a woman's right to choose has become widespread within abortion services, with the majority of abortions provided by charities operating with an explicitly pro-choice vision; and entrenched in professional guidance. ${ }^{11}$ This is reflected in how the law is interpreted in day-to-day practice. ${ }^{112}$ Women's experience of accessing services will thus be very different in 2018 , notwithstanding the fact that such access is governed by exactly the same statutory requirements.

A focus on the medical gatekeeper role and critical scrutiny of the appropriate exercise of clinical discretion was also central to the recent Daily Mail 'sting', which strongly echoes some of the allegations made in Babies for Burning. Notably, the Mail also criticises the construction of a narrative designed to meet the terms of the Abortion Act.

When a Mail reporter contacted Marie Stopes saying she wanted an abortion, she was told there was no need to meet the doctor who would give the go-ahead because it was routine for doctors to fill out the necessary forms 'behind the scenes', based on the reason she gives the clinic's call centre staff.

The call centre worker told her: 'We've already done the legal side of things. It's done before [you get to the clinic]'. This is despite the fact that when asked for a reason, the reporter said: 'I just

\footnotetext{
${ }^{106}$ The award of one halfpenny left Bloom liable for an estimated $£ 20,000$ in costs that had accrued beyond the time that the paper had paid $£ 5$ into court: Anon 'Sex expert wins 1/2p damages over abortion libel' (Guardian, 11 March 1977).

${ }^{107}$ Bloom, above n 52. See further, Smith, where the CA were critical of the trial judge's failure to permit evidence on the practice of other doctors, above n 92, 384 .

${ }^{108} \mathrm{M}$ Waite 'Consultant psychiatrists and abortion' [1974] 4 Psychol Med 74 found that, by 1971, 35\% of consultant psychiatrists would recommend termination for any woman who had requested it before ten weeks, provided that she had seriously considered alternatives.

${ }^{109}$ Smith, above n 92.

${ }^{110}$ Department of Health, above n 68.

${ }^{111}$ RCGP Position Statement on Abortion (2 April 2012), available at www.rcgp.org.uk/policy/rcgp-policy-areas/ /media/ Files/Policy/A-Z-policy/RCGP_Position_Statement_on_Abortion.ashx.

${ }^{112}$ Ibid. Generally S Sheldon 'British abortion law: speaking from the past to govern the future' (2016) 79(2) Modern Law Review 283.
} 
don't want the baby' - which, on its own, is not considered sufficient grounds for an abortion under the Act.

By the time the reporter got to the clinic, her 'I just don't want the baby' justification had been recorded in her medical notes as 'client is unable emotionally to continue with pregnancy', which fits the legal conditions. ${ }^{113}$

While the similarities are clear, however, the differences in the findings of the two investigations are also stark. The Bloom interview had taken 30-40 minutes and included more than 90 questions, ranging from the subject of Kentish's marriage to her early childhood and history of bedwetting. Moreover, this was Kentish's second appointment with a doctor: she had already met and discussed her situation with the gynaecologist who would perform the abortion. The Mail investigation claimed, however, that MSI doctors approved abortions for women who would be 'signed off ... based on only a brief conversation with a call staff worker', with exploration of the woman's reasons for ending a pregnancy lasting as little as 'just 22 seconds'. It further highlighted the CQC's concerns about doctors 'bulk signing' abortion consent forms without seeing the women involved, with one doctor said to have signed 26 forms in two minutes. ${ }^{114}$

The Mail reports excited nothing like the attention of Babies for Burning. They were not widely covered by other newspapers and have not resulted in legal or disciplinary investigation into anyone involved. While services were temporarily suspended at MSI clinics following the CQC report noted above, this decision was made on the basis of other flaws within the service, which gave concern for patient safety. ${ }^{115}$ This implies a very different understanding of the medical gatekeeper role than that seen in Bloom, reflecting a widespread acceptance (in both legal and broader terms) of a far lower level of medical scrutiny before a woman is granted access to a legal abortion. Today, contestation rather focuses on whether either of the two certifying doctors must see the woman in person and how much time is needed in order to reach a good faith view, ${ }^{116}$ with the Mail and CQC reports suggesting that the bar is now set at a low level. Indeed, Bloom's detailed questioning of Kentish might appear inappropriately intrusive to modern eyes, in the light of broader acceptance that a married woman might seek an abortion simply because she does not want to become a mother, without needing to display some underlying neurosis.

A statute acquires meaning across its life both through judicial determination and through the local, interpretative work of those who work within it. While some doctors immediately took a liberal interpretation of the Abortion Act, it took years of individual, daily acts of interpretation for this approach to become consolidated into the mainstream orthodoxy that exists today. ${ }^{117}$ And it is clear from the above that the processes of gleaning and interpreting information which underpin the decision to authorise an abortion have evolved considerably over the decades. The result is that this key legal requirement for a 'good faith' opinion means something very different in the early 1970s and in 2018. While Bloom's detailed questioning of Kentish would be seen as unnecessary and inappropriately intrusive today, the practices described by the Daily Mail would surely have been deemed illegal in the 1970s.

The processes of negotiation and mutual accommodation involved in how an Act is applied and how it impacts in practice always require empirical investigation. ${ }^{118} \mathrm{~A}$ biographical approach relies upon this fundamental socio-legal insight, while foregrounding the need to be attentive to both continuity (in the written text and the settling of received interpretations) and change (amendment to the text, evolution or points of rupture in those interpretations). While the text of the Abortion Act has

\footnotetext{
${ }^{113}$ Faulkner and Smyth, above n 23.

${ }^{114}$ Ibid.

${ }^{115}$ CQC, above n 70 .

${ }^{116}$ Generally Department of Health Guidance in Relation to Requirements of the Abortion Act 1967 (May 2014).

${ }^{117}$ RCGP, above n 111; Sheldon, above n 112.

${ }^{118}$ Nelken, above n 15, p 212.
} 
remained largely unaltered since 1967, it has acquired meaning as its terms have been implemented and consolidated within day-to-day practice, received understandings of appropriate treatment, the policies and procedures of service providers, codes of professional ethics, evolving official guidance and regulation. ${ }^{119}$ While the development of legal doctrine is important, such meaning is developed not just by lawyers but also by a range of other actors. In the present case, reference to contemporary medical practice has been an important part of fleshing out that meaning: the Act has both impacted on such practice and been read in ways that are influenced by changes within it. While the liberal interpretation which some doctors have given to the Abortion Act has been subject to occasional obiter judicial criticism, ${ }^{120}$ the courts have nonetheless accepted broad clinical discretion in the interpretation and application of the legislation. As Sir George Baker P famously put it: '[n]ot only would it be a bold and brave judge who would seek to interfere with the discretion of doctors acting under the Act, but I think he would really be a foolish judge'. ${ }^{121}$

\section{Continuity and change in broader narratives}

An Act's biography includes not merely developments that flesh out its legal meaning and guide its day-to-day implementation. It also involves the accumulation and entrenchment of, and occasional points of rupture in, public narratives reflecting what the law symbolises in broader socio-cultural terms. For example, however convincingly this story was subsequently rebutted, one thing that some people 'know' about the Human Rights Act (1998) is that it allows an illegal immigrant to avoid deportation if he has a pet cat, ${ }^{122}$ with this playing to a broader concern that the Act offers an affront to common sense British values and sovereignty. ${ }^{123}$ Such narratives can enjoy a significant influence, despite having no self-evident, direct relationship to the legal meaning of the text of a law as it exists 'on the books'. ${ }^{124}$ Notably, what a law comes to symbolise in the popular imagination is crucial in shaping opinion regarding the need for its retention, reform or abolition. As for any human subject, these broader narratives form an essential aspect of its story.

From the first, this symbolic dimension of the Abortion Act was fiercely contested. Its supporters praised it as offering a crucial advance in public health and as a humane, far-sighted piece of legislation. ${ }^{125}$ Its critics, however, attacked it as representing a transgression 'against the very basis of our mortal existence', ${ }^{126}$ and facilitating the operation of a squalid 'abortion industry' that had profiteered at the expense of women's misery and offered a 'vehicle on which man can escape from his responsibilities' ${ }^{127}$ In this light, the two media investigations discussed above were each concerned with far wider issues than the actions of those named within them and indelibly marked by ongoing struggle regarding the morality of abortion and the 'truth' of the Abortion Act. ${ }^{128}$

At their most general, the claims made in Babies for Burning tapped into cultural anxieties regarding a changing Britain. The greater availability of abortion services was part of a broader shift towards public acceptance, and greater visibility, of women taking control of their own fertility and planning their families, ${ }^{129}$ facilitating their wider participation in the public sphere. The fundamental challenge

\footnotetext{
${ }^{119}$ Sheldon, above $\mathrm{n} 112$, for detailed discussion of this co-evolution.

${ }^{120}$ Eg Lord Denning MR, $R C N$, above $\mathrm{n} 78$, at 554; Cooke J, $R v$ Catt (17 September 2012) at [15].

${ }^{121}$ Paton $v$ BPAS [1978] 2 All ER 987 at 992.

${ }^{122} \mathrm{BBC}$ News 'Theresa May under fire over deportation cat claim' (4 October 2011).

${ }^{123} \mathrm{~T}$ Stanley 'Scrapping the Human Rights Act won't abolish human rights' (Telegraph, 1 June 2015).

${ }^{124}$ Nelken, above n 15.

${ }^{125}$ Editorial, above n 4 .

${ }^{126}$ Muggeridge, above n 5 .

${ }^{127}$ Litchfield and Kentish, above n 24, p 182.

${ }^{128}$ For example, for the BPAS Public Relations Officer, BPAS's defamation action was primarily about defending the Abortion Act: 'the "stories" have taken a hold in the public consciousness and, in my experience, are trotted out as "the truth about the abortion situation" whenever the matter is discussed': D Munday, memo to Rubinstein Callingham (5 May 1977), BPAS archive, Evidence 4.

${ }^{129}$ The Family Planning Act 1967 made contraception readily available through the NHS.
} 
which this posed to existing gender and familial norms was fiercely contested: one leading Pro-Life MP had attacked the campaign for the Abortion Act as a stampede of 'shrill atypical feminist abortionists, often childless, who in their demands for women's rights trample upon women's needs'. ${ }^{130}$ Others lamented a casualisation of attitudes towards the taking of human life and the decline in religious norms which this represented. The veteran journalist, Malcolm Muggeridge argued passionately that the 'abortion controversy is the most vital and relevant of all':

'Either we go on with the process of shaping our own destiny without reference to any higher being than Man, deciding ourselves how many children shall be born, when and in what varieties, and which lives are worth continuing and which should be put out [...] Or we draw back, seeking to understand and fall in with our Creator's purpose for us rather than to pursue our own, in true humility praying, as the founder of our religion and our civilisation taught us. Thy will be done. ${ }^{131}$

The narratives spun around the Abortion Act have evolved considerably since that time, with faithbased claims far less prominent in contemporary debates. Fertility control has come to be broadly accepted not just as a right but also, increasingly, a responsibility. ${ }^{132}$ Some strong threads of continuity are nonetheless apparent. Notably, concerns that non-NHS providers may be exploiting women for profit and references to a 'profit-hungry' 'abortion industry' have long outlived the concrete examples of taxi touts and cash payments in 'grubby notes' which fuelled the imagination of Babies for Burning, persisting today in a context where such providers are typically charities operating under NHS contract.

Much more recently, a concern that profit-oriented service providers might influence women in favour of termination afforded the context for a statutory amendment, tabled by Nadine Dorries MP. This would have required that women should be offered 'independent' counselling before accessing abortion services, with 'independent' defined to include only statutory bodies and those private organisations which had no financial interest in providing abortion services. ${ }^{133}$ The same concern was clear in Maria Caulfield MP's opposition to a recent Ten Minute Rule Bill seeking the decriminalisation of abortion. Referencing the Mail investigation, Caulfield argued that:

'the UK abortion industry is knee-deep in revelations of unethical, unsafe and unprofessional practices [...] No wonder these abortion providers are calling for a Bill that would get rid of the regulations and safeguards in the Abortion Act'. ${ }^{134}$

In the same way as Babies for Burning, Caulfield here generalises concerns regarding one non-NHS service provider to attack an 'abortion industry', ignoring the fact that one charity had led the campaign for reform, ${ }^{135}$ whilst criticisms of unsafe and unprofessional practice had related exclusively to another. ${ }^{136}$

While there is thus clear continuity in concerns regarding doctors' role in approving abortions, there are also strong differences in how these are contextualised in 1974 and 2017. In Babies for Burning, criticism of the exercise of clinical discretion is located within a powerful concern that doctors' failure to fulfil the gatekeeper role in the way foreseen in the Abortion Act has resulted in women

\footnotetext{
${ }^{130}$ L Abse Private Member (London: Macdonald, 1973) p 230.

${ }^{131}$ Muggeridge, above n 5.

${ }^{132}$ J Bristow The Sociology of Generations: New Directions and Challenges (London: Palgrave, 2016) ch 5.

${ }^{133}$ Clause 10, amendments 1 and 2, tabled to the Health and Social Care (Re-committed) Bill, HC Deb, vol 532, cols 362-391, 7 September 2011. This would have prevented charitable abortion service providers from counselling women who they then might go on to treat.

${ }^{134} \mathrm{HC}$ Deb, vol 623, col 30, 13 March 2017.

${ }^{135}$ See BPAS 'We Trust Women campaign' at www.wetrustwomen.org.uk/.

${ }^{136}$ CQC, above n 70; Faulkner and Smyth, above n 23.
} 
being wrongly accorded access to abortions that they should properly have been denied. Litchfield and Kentish adopted a 'shallow cover story' of 'a childless, utterly selfish, self-seeking and self-indulgent married couple who could have no possible reason in the world for qualifying for an abortion under the Act' because 'if it was possible for us to buy an abortion ... then we had proven beyond all doubt that a state of abortion on demand exists in Britain, which is contrary to both the law and the claims of successive Governments.'. ${ }^{137}$

In contrast, the Mail report makes no suggestion that women are selfish for seeking abortion nor that they should be refused access to services. Rather it foregrounds concerns for women's welfare and safety in how those services are offered. ${ }^{138}$ The main report contains a link to an earlier article describing the '2,600 safety flaws' uncovered by the CQC, which had led to services being temporarily suspended at MSI. It is accompanied by a report from a retired doctor who had worked at MSI and an interview with a woman who had been treated there, which each describe flawed consent procedures leaving some women unable to voice doubts about their decisions to have an abortion. ${ }^{139}$ These 'women protective' concerns are also visible in Babies for Burning but as abortion on request has become more widely accepted, at least in early pregnancy, they now offer the dominant frame for criticisms of the regulatory regime. ${ }^{140}$

One final point is noteworthy regarding Maria Caulfield's intervention above: rather than attacking the Abortion Act's role in facilitating bad practice, a Pro-Life MP here cites the dangers of such practice as a reason for defending the 'regulations and safeguards' which the Act offers. As noted, Caulfield's intervention was provoked by a Bill seeking to liberalise the law. ${ }^{141}$ While it is too early to judge, it is possible that this may mark a new stage in the Abortion Act's life story: as it comes to be attacked as outdated and redundant by those seeking liberalising reform, ${ }^{142}$ it may find itself defended, and possibly even praised, by Pro-Life commentators.

Legislation cannot hope to resolve political and ethical disputes but, rather, offers an important site upon which they may continue to play out. ${ }^{143}$ The stories told about the Abortion Act are clearly marked by this ongoing struggle, as well as reflecting other contemporary concerns: current debates regarding sex selective abortion, for example, focus on particular ethnic communities and are clearly refracted through prisms of race and gender. ${ }^{144}$ Alternatively, narratives may lose force as the broader concerns on which they draw fade from memory. In the 1970s, Babies for Burning's allegation that a doctor would sell aborted fetuses to be made into soap would have echoed powerfully with stories which had circulated during both World Wars but are less familiar, and thus almost certainly less credible, today. ${ }^{145}$ However, the current anxieties reflected in the allegations made against MSI are strongly rooted in persistent narratives regarding an 'abortion industry', which operates with a strong concern for profit and little regard for women. The Mail's claim that a woman's reasons for requesting an abortion can be explored in just 22 seconds also speaks powerfully to an ongoing

\footnotetext{
${ }^{137}$ Litchfield and Kentish, above n 24, p 76.

${ }^{138}$ CQC, above n 70.

${ }^{139}$ J Parsons 'The abortion conveyor belt'; S Smyth 'There were lots of crying women ... I'd never go through it again' (Daily Mail, 5 March 2017).

${ }^{140} \mathrm{RB}$ Siegel 'The new politics of abortion: an equality analysis of woman-protective abortion restrictions' (2007) University of Illinois Law Review 990, on the turn towards 'woman protective' arguments.

${ }^{141}$ Diana Johnson MP, Ten Minute Rule Bill, HC Deb, vol 623, cols 26-28, 13 March 2017.

${ }^{142} \mathrm{Eg}$ BPAS, above $\mathrm{n} \mathrm{135}$; S Sheldon 'The decriminalisation of abortion: an argument for modernisation' (2016) 36(2) OJLS 334.

${ }^{143} \mathrm{C}$ Smart Feminism and the Power of Law (London: Routledge, 1989); J Harrington 'Of paradox and plausibility: the dynamic of change in medical law'(2014) 22(3) Med L Rev 305 using abortion to illustrate the claim that medical law offers 'the venue for a range of social conflicts'.

${ }^{144}$ Generally E Lee 'Constructing abortion as a social problem: “sex selection” and the British abortion debate' (2017) 27(1) Feminism \& Psychology 15.

${ }^{145}$ On the Nazi use of human cadavers to produce soap: B Shallcross The Holocaust Object in Polish and Polish-Jewish Culture (Indiana UP, 2011) ch 3.
} 
concern that the Abortion Act has supported a trivialisation of abortion and a casualisation of attitudes to human life. ${ }^{146}$

\section{Biography as a window onto the wider world}

Finally, and briefly, there is no such thing as a life lived in isolation. ${ }^{147}$ Biography implies the exploration of the 'fish' and also the 'stream in which it swam', ${ }^{148}$ offering not just a 'character-in-an-environment' but also a 'character as a way of discovering an environment'. ${ }^{149}$ The biography of a statute should offer not just study of how its meaning is influenced by broader changes in the contexts within which it operates, but also an important window onto the world around it, permitting a tightly focused study of any one of the evolving contexts that have impacted on spatial and temporal variation in its interpretation and implementation.

In spatial terms, divergent interpretations of the Abortion Act in different areas permit an exploration of the (waning) influence of local, senior doctors in different regions and changing mechanisms of NHS funding on service provision. ${ }^{150}$ At a national level, the differential impact of the Abortion Act in Scotland, as compared to England and Wales, speaks to wider differences in the legal context within which it operates, ${ }^{151}$ the different history of service provision in the different countries which make up the UK, and the key roles played by individuals in how a statute is implemented. ${ }^{152}$ Notably, the fact that abortion services were accommodated within NHS facilities has meant that private and charitable providers were not established in Scotland in response to gaps in provision and concerns regarding the development of an 'abortion industry' did not bite in the same way. ${ }^{153}$ The fact that the Abortion Act does not extend to Northern Ireland offers a window onto the powerful influence of religion in that jurisdiction, the particularities of the political context, matters of national identity, and the parameters of devolution. ${ }^{154}$ The Abortion Act has also been an important focus in ongoing dispute regarding how law should - or should not - be reformed in both Northern Ireland and the Republic of Ireland, ${ }^{155}$ and this is an important part of its story.

A biography of the Abortion Act can also offer a window onto a range of significant changes across time. ${ }^{156}$ First, the broad meaning given to the requirement that an abortion be 'performed by a registered medical practitioner' reflected technological developments that had moved abortion out of the operating theatre, making it a far safer, technically less demanding procedure. ${ }^{157}$ An analysis of the interpretation and implementation of this provision of the Abortion Act might also offer an insight into health professionals' changing roles within the interdisciplinary medical team, with $R C N$

\footnotetext{
${ }^{146}$ See generally Alton, above n 6.

${ }^{147}$ Lee, above n $11, \mathrm{p} 13$.

${ }^{148}$ Woolf, above $\mathrm{n} 21$.

${ }^{149}$ B Pimlott 'Is contemporary biography history?' (1999) 70(1) The Political Quarterly 31 at 39. In the context of object biography, Kopytoff, above n 18, p 67.

${ }^{150}$ Paintin, above n 8, pp 62-64, on the impact of changing NHS funding mechanisms.

${ }^{151} \mathrm{~K}$ Norrie 'Abortion in Great Britain: one act, two laws' (1985) Crim L Rev 475.

${ }^{152} \mathrm{G}$ Davis and R Davidson "The fifth freedom" or "hideous atheistic expediency": the medical community and abortion law reform in Scotland, c 1960-75’ (2006) 50(1) Medical History 29.

${ }^{153}$ Generally, ISD, above $\mathrm{n} 68$.

${ }^{154} \mathrm{G}$ Horgan and JS O'Connor 'Abortion and citizenship rights in a devolved region of the UK' (2014) 13(1) Social Policy and Society 39; G Horgan 'A holy alliance? Obstacles to abortion rights in Ireland north and south' in A Quilty, S Kennedy and C Conlon (eds) The Abortion Papers Ireland: Volume 2 (Cork, Attic Press, 2015).

${ }^{155} \mathrm{R}$ Fletcher 'Post-colonial fragments: representations of abortion in Irish law and politics' (2001) 28(4) JLS 568.

${ }^{156}$ Here, biography shares some similarities with 'micro history', which focuses on a small area, narrow time band, or tightly defined community to illuminate something more general: see generally SG Magnússon and IM Szijárto What is Microhistory? Theory and Practice' (London: Routledge, 2013). We thank David Sugarman for this observation.

${ }^{157}$ Sheldon, above n 112; J Olszynko-Gryn 'Technologies of contraception and abortion' in N Hopwood, R Flemming and L Kassell (eds) Reproduction: Antiquity to the Present Day (Cambridge: Cambridge University Press, forthcoming).
} 
revealing the dominance of medicine over nursing and midwifery in the early 1980s. ${ }^{158}$ For Lord Denning, a restrictive interpretation of the Act was necessary to protect nurses, 'young women who are dedicated by their profession and training to do all they can to preserve life' from 'soul-destroying' work, by requiring those doctors minded to prescribe abortions to perform them themselves. ${ }^{159}$ The contrary interpretation, adopted by a slim majority in the House of Lords, relied on the view that the nurses' actions were legally those of the doctors, representing nurses as little more than doctors' 'handmaidens'. ${ }^{160}$ Each view stands in stark contrast to a far less hierarchical, contemporary view that the different professions each bring discrete competences to a multidisciplinary 'team effort'. ${ }^{161}$

Secondly, today Bloom's view - that abortion should be available to any woman who wants one has become a widespread orthodoxy within modern British abortion services, at least in the context of early pregnancy. ${ }^{162}$ The dominance of the corresponding, permissive interpretation of the Abortion Act may be read as reflecting broader shifts in jurisprudence and professional ethics, which have each moved away from an acceptance of paternalism (where a doctor's duty of beneficence towards the patient might justify his or her primary responsibility for important decisions) towards a strong foregrounding of the need to respect patient autonomy. ${ }^{163}$ Changes in the application of the Act might also reflect a growing public acceptance of women's rights to control their own fertility and the consequent need for abortion services as an integral part of women's healthcare. In this sense, the story of the Abortion Act can offer a window into broader shifts in understandings of gender roles and patterns of childrearing. Finally, it also offers a powerful illustration of the declining power of religious norms and the growing prevalence of the view castigated above, that people might 'shap[e] our own destiny without reference to any higher being than Man'. ${ }^{164}$

\section{Conclusion}

If biographical information regarding an object inheres in the patina of age, wear and repair acquired through its life, ${ }^{165}$ then for a statute it is to be found in amendments made to its text; legal doctrine giving meaning to its provisions; practices which it influences and which may, in turn, influence its interpretation; its impact in the physical world; and the shifting symbolic meanings that it acquires across time and space. The idea of biography offers a shorthand for an approach which requires simultaneous attention to both continuity and change in these aspects of a law's life. It takes seriously the insight that written norms are rooted in the past, enshrining a specific set of historically contingent values and practices, yet that - as linguistic structures which can impact on the world only through acts of interpretation - they are simultaneously constantly evolving. ${ }^{166}$ It acknowledges the complex, ongoing co-constitution of law and the contexts within which it operates, recognising that understanding how law works requires historical, empirical study. Finally, it suggests that consideration of a law can offer a unique window through which to explore these broader contexts, serving as 'a thread of continuity through changing times'. ${ }^{167}$

Taken individually, each of these insights is likely, to a greater or lesser extent, already to be familiar to both socio-legal scholars and legal historians. Earlier work has described the historical

\footnotetext{
${ }^{158} \mathrm{~J}$ Montgomery 'Doctors' handmaidens: the legal contribution' in S McVeigh and S Wheeler (eds) Health, Health Regulation and the Law (Aldershot: Dartmouth, 1992) p 141.

${ }^{159} R C N$, above $\mathrm{n} 78$, at $555,557$.

${ }^{160}$ Montgomery, above n 158.

${ }^{161}$ Lady Hale has read $R C N$ to mean that the statutory requirement is met when the abortion is 'a team effort carried out under [the doctor's] direction, with the doctor performing those tasks that are reserved to a doctor and the nurses and others carrying out those tasks which they are qualified to perform'. Doogan, above n 78, at [9].

${ }^{162}$ Eg RCGP, above n 111.

${ }^{163}$ Generally Sheldon, above n 112.

${ }^{164}$ Muggeridge, above n 5 .

${ }^{165}$ J Joy 'Reinvigorating object biography' (2009) 41(4) World Archaeology 540 at 545.

${ }^{166}$ J Black 'Regulatory conversations' (2002) 29(1) JLS 163 at 172.

${ }^{167}$ Pimlott, above n 149 , at 41.
} 
circumstances which gave rise to the passage of specific statutes; ${ }^{168}$ emphasised how individual cases must be understood within a broader historical context; ${ }^{169}$ explored the legal impact of persistence or shifts in such contexts; ${ }^{170}$ discussed how the meaning of a specific legal concept can evolve across time; ${ }^{171}$ analysed how understandings of law and legality are refracted through broader cultural anxieties at particular times; ${ }^{172}$ considered how legal reasoning relies on rhetorical strategies likely to prove persuasive to concrete audiences within specific historical, cultural and political contexts; ${ }^{173}$ described how an 'inherited regulatory environment' informs the interpretation and implementation of any law; ${ }^{174}$ and discussed what socio-legal scholars might learn from legal history. ${ }^{175}$ However, the approach proposed here combines these insights in ways which are either new or, at least, uncommon in existing socio-legal scholarship, with biography's simultaneous attention to change and continuity over an extended period offering the potential for a richer and more nuanced appreciation of law. While we must leave it to others to explore what insights might be gleaned in the study of other specific laws, we have suggested that this approach has much to contribute to understanding the Abortion Act (1967), a statute which has exhibited considerable longevity in an evolving, highly controversial field.

Any way of seeing is, of course, also a way of not seeing, with any given approach bound to reveal only those aspects of law that are possible for it to fathom through the assumptions, protocols and methods of its own knowledge-practices. ${ }^{176}$ One implication of a biographical approach is that, by its nature, it foregrounds the study of one particular law rather than aiming to provide a comprehensive account of the regulatory field, which - in the context of abortion services - would involve mapping an extremely complex and constantly shifting legal landscape. ${ }^{177}$ An inherent risk of a biographical approach to law might thus echo that sometimes made of human biography: in focusing on one life, it is liable to miss the broad sweep of history, giving too much weight to individual impact divorced from the broader behaviour of groups. ${ }^{178}$ Secondly, and seemingly against the grain of much socio-legal scholarship, in starting from the study of a particular statute rather than from people's experience, a biographical approach might be criticised for appearing to offer a 'law-first' approach. ${ }^{179}$

A third, somewhat contradictory concern, which may begin to respond to the first two, is that the boundary between 'fish' and 'stream' is always and inevitably unclear in the context of the biography of

\footnotetext{
${ }^{168}$ Above n 15.

${ }^{169}$ AWB Simpson Cannibalism and the Common Law (London: Penguin, 1986), locating $R v$ Dudley and Stephens within a broader conflict 'between the old custom of the sea and the comfortable morality of the common law', p 271.

${ }^{170}$ A Ballinger 'A muted voice from the past: the "silent silencing" of Ruth Ellis' (2012) 21(4) SLS 445, showing how the appeal in Ruth Ellis's case, 48 years after her trial and execution, reveals important continuities within the operation of the legal system with respect to the social control of women.

${ }^{171}$ We are grateful to Dave Cowan for the example of Lady Hale's discussion of evolution in the meaning of 'violence' in Yemshaw v London Borough of Hounslow [2011] UKSC 3; see also Fitzpatrick v Sterling Housing Association Ltd [2001] 1 AC 27 on the evolving meaning of 'family'.

${ }^{172}$ Eg S Hall et al Policing the Crisis: Mugging, the State, and Law and Order (London: Macmillan, 1978); P Golding and S Middleton Images of Welfare: Press and Public Attitudes to Poverty (Oxford: Martin Robertson, 1982).

${ }^{173}$ J Harrington Towards a Rhetoric of Medical Law (Routledge, 2017).

${ }^{174}$ E Stokes 'Nanotechnology and the products of inherited regulation' (2012) 39(1) JLS 93.

${ }^{175} \mathrm{D}$ Sugarman 'Promoting dialogue between history and socio-legal studies: the contribution of Christopher W Brooks and the "legal turn" in early modern English history' (2017) 44(5) JLS 37.

${ }^{176} \mathrm{~K}$ Burke Permanence and Change (New York: New Republic, 1935) p 70; D Nelken, Beyond Law in Context: Developing a Sociological Understanding of Law (Ashgate, 2009) p xiii.

${ }^{177}$ In addition to the general principles of criminal and civil law, the BMA Decriminalisation of Abortion: a Discussion Paper from the BMA (February 2017) pp 15-16, notes 14 specific statutes, regulations and codes of professional guidance which would be relevant to such an exercise.

${ }^{178}$ Generally, Pimlott, above n 149.

${ }^{179}$ P Ewick and S Silbey The Common Place of Law (University of Chicago Press, 1998) p 20, criticise the 'law-first' tradition of legal scholarship as excluding study of 'how, where, and with what effect law is produced in and through commonplace social interactions'; see further D Cowan 'Legal consciousness: some observations' (2004) 67(6) MLR 928.
} 
a law. ${ }^{180}$ In other words, any study purporting to be focused on a specific statute risks collapsing into a broader study of the regulatory field, the behaviour of the individuals who operate within it, and beyond that, the shifting environment within which law operates. In this sense - and here is our response to the first concerns - while it focuses on a particular law, the biographical approach seeks to capture how law, day-to-day practices and popular understandings develop through a process of ongoing, mutual constitution, with formal legal agents just one subset of the wider range of individuals actively involved in law-making. ${ }^{181}$ Indeed a study, such as our own, which traces change and continuity across time is inevitably concerned precisely with exploring such co-constitution. ${ }^{182}$ And to return to the issue of the boundary between fish and stream: this is a familiar problem for socio-legal scholars, who are used to dealing with the messiness of law and the difficulty of defining the boundaries of 'the legal'. ${ }^{183}$ We thus recognise this as an important issue of which all socio-legal scholars must remain aware, rather than admitting it as a specific methodological problem for the biographical approach.

In defending human biography from the charge that it is liable to miss the broad sweep of history, one eminent historian and biographer has written:

'writing a biography is like entering a deep cavern. The cavern is a human life, the walls of the cavern are the evidence. From the lie of the land, you can tell that the cavern is likely to be an interesting one. But until you light your lamp and crawl around, you don't know what you will find. You will never get the whole picture; there will always be crevices out of reach. But the project is finite, and when your exploration is finished you will have, not only a unique appreciation of the particular cave, but a better feeling for geology in general'. ${ }^{184}$

Similarly, the biography of one important statute can offer a unique appreciation of the operation of that one law and a narrow focus for analysing important trends in the broad sweep of history throughout its duration, as well as casting broader light on the way in which any law acquires meaning over its lifetime. A biographical approach cannot hope to resolve the issue of the 'messiness' of law and nor should it; it can, however, add to a full appreciation of its complexity.

\footnotetext{
${ }^{180}$ We thank John Coggon for this observation.

${ }^{181}$ Ewick and Silbey, above n 179, p 20.

${ }^{182}$ We thank Dave Cowan for this observation. See generally, Ewick and Silbey, above n 179; Cowan, above n 179.

${ }^{183}$ Generally Cowan and Wincott, above n 19; Ewick and Silbey, above n 179.

${ }^{184}$ Pimlott, above n 149.
}

Cite this article: Sheldon S, Davis G, O’Neill J, Parker C (2019). The Abortion Act (1967): a biography. Legal Studies 39, 18-35. https://doi.org/10.1017/1st.2018.28 